\title{
MODELLING AS AN IMPORTANT PART OF EDUCATION
}

\section{Libuša RÉVÉSZOVÁ}

\begin{abstract}
In the article there is described application of new trends in the field of modelling in academic education - object oriented methods of modelling information systems and business processes, analysis of user requirements and supporting of students creativity using a project method.
\end{abstract}

Key words: education, modelling, information system, business process.

\section{MODELOVANIE AKO DÔLEŽITÁ SÚČASŤ VÝUČBY}

Resumé: V príspevku sa zaoberáme úlohou modelovania vo vyučovaní, hodnotením a skúsenostami $z$ výučby modelovania a základov informačných systémov. Opisujeme možnosti využitia projektovej metódy, najmodernejších objektovo orientovaných metód modelovania a analýzy použivatel'ských požiadaviek a podporou tvorivosti študentov.

Kl'účové slová: vzdelávanie, modelovanie, informačný systém, podnikový proces.

\section{1 Úvod}

Vývoj smerom k znalostnej spoločnosti neustále zvyšuje nároky na človeka, aby mohol vykonávat' svoju prácu, dokázal sa presadit', bol úspešným a flexibilným. Je všeobecne známe, že radikálne rastie význam vzdelávania. V súčasnosti je nadobúdanie nových poznatkov, vedomostí, zručností a znalostí investícia, ktorá napomáha ekonomickému rastu, prispieva $\mathrm{k}$ individuálnemu a spoločenskému rozvoju, redukuje sociálnu nerovnost'.

Moderne koncipovaný edukačný proces môže urobit' vel'a pre získanie samostatnosti, tvorivosti a komunikatívnosti jedinca. Dôležitou podmienkou progresívneho dynamizmu vzdelávacieho systému je odstraňovanie zastaraného obsahu, foriem, metód, procedúr, ktoré nie sú adekvátne vývojovým potrebám spoločnosti. Modernizácia sa stáva jedným z atribútov pedagogického úsilia [16]. Pokúsime sa načrtnút' význam modelovania a možnosti jeho využitia ako dôležitého prvku pri modernizácii vzdelávania.

\section{Modelovanie ako nástroj poznania}

Modelovanie ako jedna z najrozšírenejších metód poznávania má dávnu históriu. Najrôznejšími prostriedkami (verbálnym opisom, graficky, pomocou matematickej symboliky, fyzikálne a technicky realizovanými modelmi, ...) sa človek snažil opísat' veci, ktoré sa nachádzali v jeho prostredí, javy, ktoré pozoroval. Produktom úvah boli modely zavedené najčastejšie abstraktným spôsobom, ktoré vyjadrovali podstatné vlastnosti reálnych systémov - objektov, ktoré boli predmetom záujmu človeka.

V súčasnosti zrejme neexistuje človek, ktorý by sa nestretával $\mathrm{s}$ použitím princípov modelovania, vyplývajúcich zo samej podstaty prírody a jej zákonitostí. $\mathrm{Aj} \quad \mathrm{v}$ celkom neuvedomelom chápaní podobnosti a analógie javov možno vystopovat' základný princíp spoločný rôznym druhom modelovania jednoznačné priradenie dvoch rôznych systémov sebe navzájom (reálny systém - model) [9].

Tvorba modelov - modelovanie vyžaduje aktívnu a tvorivú činnost' človeka, v súčasnosti s významnou podporou a využitím technológií. Je dôležité uvedomit' si aký vel'ký význam a praktické aplikácie má modelovanie $\mathrm{v}$ živote človeka, počínajúc učením a hrami najmenších detí, následne v školskom vzdelávaní. Vel'ká čast' úloh a problémov $\mathrm{v}$ pracovnom $\mathrm{i}$ každodennom živote je taktiež spojená s tvorbou či ohodnotením rôznych modelov reálneho sveta.

Modelovanie bolo a je prostriedkom hlboko ovplyvňujúcim spôsob vedeckého myslenia. Vysoký stupeň abstrakcie, uplatňovanie praktickej skúsenosti, intuície i citu vytvárajú z modelovania špecifickú formu umenia experimentu. Modelovanie sa chápe ako základ vedeckého skúmania javov [9].

Model je abstrakciou toho, čomu chceme porozumiet' ešte predtým, ako to vybudujeme. Model neobsahuje nepodstatné detaily, l'ahšie sa $\mathrm{s}$ ním manipuluje ako $\mathrm{s}$ originálnou entitou. Abstrakcia, používaná pri modelovaní, je základná schopnost' človeka, ktorá umožňuje narábat' so zložitými komplexmi. Inžinieri, 
umelci, stavitelia si už pred tisíckami rokov pripravovali modely, prostredníctvom ktorých sa pokúšali navrhnút' a optimalizovat' to, čo chcú vytvorit'. Na to, aby sa vybudoval komplexný systém sa musia pomocou rôznych pohladov a presnej notácie vytvorit' modely. Je užitočné a často nevyhnutné overit', či modely splńajú požiadavky na systém a až následne systém vytvárat' a implementovat' [13].

Vytvorit' model napríklad softvérového systému skôr ako sa začne s jeho „,výrobou“, je rovnako dôležité ako nakreslit' plány domu pred tým, ako sa začne $\mathrm{s}$ jeho stavbou. Dobre vytvorený model ul'ahčuje komunikáciu medzi skupinami l'udí, ktorí sa podiel'ajú na realizácii projektu a zaist'uje, že systém bude navrhnutý rozumne. Čím je systém zložitejší, tým je dôležitejšie kvalitné modelovanie.

\section{Súčasné požiadavky a trendy vývoja}

V praktickom živote sú tvorivost' a logické myslenie často ovel'a dôležitejšie ako vecné poznatky, či zbehlost' v riešení rutinných úloh.

Skúsme sa zamysliet' nad tvrdením, uvedeným v [7] (str. 14): „Informácie sú bezcenné!“ Obzvlášt’ ak sú prístupné každému a je ich príliš vel'a. Predstavme si situáciu, že máme $\mathrm{k}$ dispozícii, napr. prostredníctvom internetu, resp. dostupných kníh, všetko $\mathrm{z}$ medicíny, čo l'udstvo vie $\mathrm{k}$ dnešnému dňu. Zrazu k nám prinesú človeka $\mathrm{v}$ bezvedomí, aby sme mu na základe toho mora dostupných informácií pomohli. Aj s vedomím možnosti, ktorú nám ponúka informačná siet', budeme schopní uvedomit' si len zopár útržkovitých poznatkov z kurzu prvej pomoci a asi budeme mat' pocit úplnej bezmocnosti, pokial' ide o využitie informácií z rozmanitých databáz.

Prečo je to tak? Čo nám chýba? Čo vytvára rozdiel medzi laikom a znalcom v prípade, že majú rovnaký prístup $\mathrm{k}$ informáciám?

Sú to súvislosti medzi informáciami, ich vnútorné zhodnotenie, včleňovanie do komplikovanejších celkov - sú to naše znalosti. Tie predstavujú skúsenosti a hodnoty organizované vo vhodných rámcoch, umožňujú hodnotenie a začlenenie nových informácií do zmysluplných, efektívne využitel'ných celkov. Znalosti sú pre toho kto ich má, predpokladom na zvládanie rôznych intelektuálnych či fyzických úkonov.

Podniky a inštitúcie sa zameriavajú na získavanie pracovníkov, ktorí sú výnimoční tým, čo vedia (,golden colar") a ako to vedia zhodnotit' v praxi. Intelektuálne výnimoční l'udia dokážu dnes (viac ako kedykol'vek v minulosti) vytvorit' perfektne fungujúce podniky podobné tým slávnym z obdobia globálnej informatizácie, ako napr. Intel (založený R. Noyce a G. E. Moorom), či Microsoft (W. H. Gatesa a P. Allena).

Práve v znalosti určitej problematiky sú dnes podstatné rozdiely medzi l'ud'mi, resp. podnikmi či inštitúciami. Informačná spoločnost' sa v krátkom čase začne (začala?) transformovat' do znalostnej, ktorá je charakterizovaná masovým sprístupňovaním a využívaním znalostí, uložených a spracúvaných podl'a požiadaviek používatel'ov [7].

Vhodný informačný systém (IS) na báze moderných informačno komunikačných technológií (IKT) v podnikoch, firmách, organizáciách, ... sa dnes javí ako nevyhnutnost'. Úspech projektov v oblasti vývoja a následnej implementácie IS, ale aj prípadných vylepšení už existujúcich, spočíva $\mathrm{v}$ efektívnom zapojení budúcich používatel'ov do budovania IS.

$\mathrm{Na}$ zdôraznenie významu kompetentnosti, zainteresovanosti a záujmu používatel'ov pri tvorbe a implementácii IS možno uviest' výsledky analýzy odpovedí 365 firiem a pre viac ako 8000 aplikácií v USA. Podl'a výskumu Standish Group sa v posledných rokoch nedokončilo v USA až $31 \%$ softvérových projektov. Viac než 52\% dokončených projektov IS prekročilo náklady takmer trojnásobne. Iba $20 \%$ projektov bolo ukončených v termíne a neprekročilo náklady.

Podl'a uvedenej štúdie boli príčiny zastavenia projektov nasledovné :

- Nekomplexnost', nejasnost' požiadaviek 22\%.

- Nedostatok záujmu a podpory zo strany používatel'ov $12 \%$.

- Nedostatok zdrojov, t. j. podhodnotený rozpočet a krátke termíny $11 \%$.

- Nerealistické očakávania $10 \%$.

- Nedostatočná podpora zo strany manažmentu dodávatel'a alebo používatel'a 9\%.

Na druhej strane, ako dôležité faktory úspechu boli uvádzané:

- Zainteresovanost' používatel'ov $18 \%$.

- Podpora manažmentu používatel'a 16\%.

- Jasne definované požiadavky $15 \%$.

- Dobré plánovanie $11 \%$.

- Realistické očakávania 9\%.

- Správna dekompozícia úloh 9\%.

- Kompetentnost' zúčastnených $8 \%$ [8], str. 24. Ked' položíme otázku čo je vlastne obsahom informačných systémov, tak sa vel'mi často 
stretávame s predstavou, že IS sú predovšetkým počítače, softvér a programovanie. Je to však mylná predstava, pretože nezahrňuje tie súčasti a činnosti v IS, ktoré sú pre celkový úspech a efektivitu rovnako významné, ak nie d'aleko významnejšie. Informačné systémy sú postavené predovšetkým na l'ud'och, ich znalostiach a schopnostiach. Ten najlepší softvér a špičkové počítače sú $\mathrm{V}$ rukách nekvalifikovaných, nekompetentných l'udí prakticky zbytočné a niekedy sú $\mathrm{v}$ týchto rukách i podstatne nebezpečnejšou zbraňou ako ceruzka a papier. Človek a jeho kvalifikácia je klúčovým prvkom celého informačného systému [2].

Vývoj metód a spôsobov využívania softvéru jednoznačne smeruje $\mathrm{k}$ znižovaniu podielu prác venovaných etapám kódovania a testovania. Prácnost' kódovania a testovania podstatne znižujú nové prostriedky vývoja, ako napr. vizuálne vývojové prostredia, objektovo orientované technológie, integrované vývojové prostredia, spolupráca aplikácií, CASE atd'. Neklesajú však nároky na účast' pracovníkov zákazníka a dodávatel'a pri analýze a modelovaní budúceho IS, rozsah školení používatel'ov, prácnost' nábehu,... [8]. Rastie význam medziodborových znalostí.

Efektivita IS je priamo závislá od schopnosti používatel'ov poskytnút' čo najlepšiu špecifikáciu svojich požiadaviek. Aj napriek skutočnosti, že vývoj a implementácia väčšiny IS je dnes doménou profesionálnych informatikov, analytikov a programátorov, bez úzkej spolupráce s používatel'mi sa integrovaný systém vybudovat' nedá. Vzhl'adom na zavádzanie, budovanie IS $\mathrm{v}$ takmer všetkých oblastiach bežnej praxe je nutné venovat' sa vzdelávaniu budúcich „používatel'ov“ s ciel'om pripravit' ich na úlohy spojené so zadaním, analýzou a modelovaním používatel'ských požiadaviek.

\section{Modelovanie vo výučbe}

Od akademického roku 2003/2004 sledujeme informačné kompetencie absolventov stredných škôl, nastupujúcich do prvého ročníka Ekonomickej fakulty Technickej univerzity v Košiciach pomocou zadania zameraného na vytvorenie modelu jednoduchého informačného systému (IS) - formulovanie používatel'ských požiadaviek. Zadanie majú študenti vypracovat' $\mathrm{v}$ prvom ročníku na prvom cvičení z predmetu Informatika I. Zaujímajú nás o. i. aj odpovede študentov na otázky, týkajúce sa modelovania a informačných systémov na základe poznatkov získaných na strednej škole.
Podrobne sme preštudovali učebnicu Informatika pre stredné školy [6], ktorá by mala byt' základom povinnej výučby informatiky na stredných školách. Všetky pojmy, potrebné pre úspešné zvládnutie úlohy, všetky podstatné nástroje, aplikácie (práca $\mathrm{s}$ textom, obrázkami, tabul'kami, základné pojmy Informatiky, základy algoritmizácie, programovania a vývoja aplikácií, technické prostriedky, teoretické východiská informatiky), ktoré sú potrebné $\mathrm{k}$ formulácii používatel'ských požiadaviek na jednoduchý IS, sa v učebnici uvádzajú. Vyskytujú sa v texte bud' priamo alebo ich autori budujú intuitívne:

- informačný systém (o.i. strany $16,24,25,38$, $73,84,86,91,95,98,100)$

- typy IS (strany $8,93,94,95,97,98$ )

- Životný cyklus (strany 45,70 )

- modelovanie (strany 45, 12, 19, 20, 96, 97)

Pre lepšiu ilustráciu uvádzame zadanie úlohy: Ste majitel' (vedúci) a $\mathrm{s}$ kamarátom (zamestnancom) obstarávate prevádzku malej požičovne nosičov (CD, DVD a pod.). Nosiče sú uložené $\mathrm{v}$ policiach, ktoré predavač vidí od pultu. Zákazník sa pri požičiavaní preukazuje kartou, ktorú mu vydá predavač pri prvej návšteve a úspešnej registrácii. $O$ tituloch sa zákazník informuje bud' sám prezeraním políc, obalov nosičov alebo u predavača. Zákazníci sú väčšinou stáli, preto je potrebné obmieňat' repertoár. Za požičanie titulu sa platí suma, stanovená majitel’om. Po uplynutí výpožičnej lehoty sa zákazníkovi posiela upomienka a platí penále.

Celá agenda sa doposial' vedie „papierovo“. Chceli by ste však prejst' na elektronický informačný systém. Ako by mal vyzerat' a fungovat'? Aké by boli vaše požiadavky na taký systém, predstavy o jeho fungovaní, napojení na okolie a pod.?

Pokúste sa zrozumitel'nou formou (písomne, graficky,...) zadat' svoje požiadavky na nový IS. Vašim požiadavkám by mali porozumiet' informatici - profesionáli, ktorí budú IS analyzovat', navrhovat' a vytvárat'. Je potrebné vyjadrit' ČO má IS robit', obsahovat', nie AKO to má robit!

Pri hodnotení vypracovaných zadaní používame nasledujúcu škálu:

A - akceptovatel'né vypracovanie, je možné rozoznat' požiadavky na to čo má IS „robit“", obsahovat'; je možné rozoznat' hierarchiu v systéme, jeho funkcie.

B - text a pokusy o grafické vyjadrenie toho čo používatel' od systému očakáva; rozsahom 
a obsahom však už nie úplné, väčšinou pokusy navrhnút' databázové tabul'ky $\mathrm{s}$ prípadným opisom dátových typov.

C - súvislý text v rozsahu $1 / 2$ strany A4 až po 2 strany A4; text vykazuje typické nedostatky rozsiahlost', vlastné výrazové prostriedky, neštrukturovanost', nejednoznačnost'.

D - text $\mathrm{v}$ rozsahu od 1 riadku po $1 / 2$ strany A4; nedostatočné, neakceptovatel'né pokusy.

E - nevypracované zadania; (zväčša uvedené „neviem čo mám napísat").

V grafe 1 a 2 uvádzame priemerné výsledky za sledované obdobie na vzorke 476 študentov.

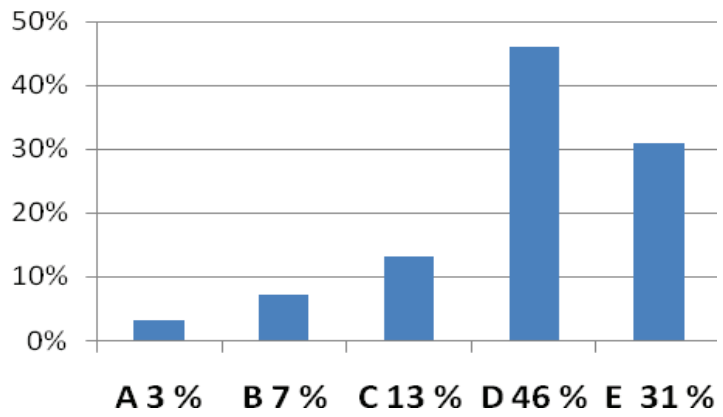

Graf 1: Úspešnost' vypracovaných zadaní.

Graf 2 prezentuje vyhodnotenie uzavretých položiek dotazníka zameraných na poznatky študentov z oblasti modelovania a IS. Otázka: Stretli ste sa na hodinách Informatiky s pojmami: I. Informačný systém (pojem, význam, ciele, ...). II. Typy IS (osobné, ekonomické, kancelárske,). III. Životný cyklus IS.

IV. Modelovanie.

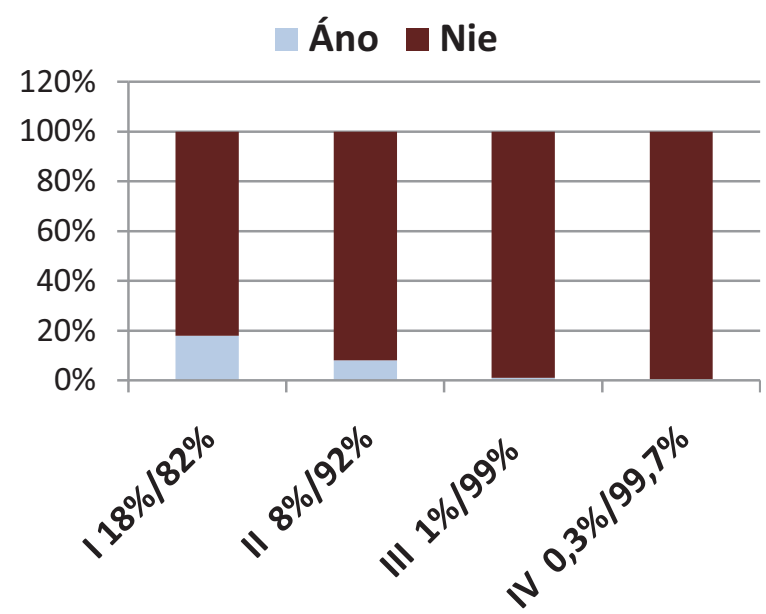

Graf 2: Vyhodnotenie odpovedí.
Ako je zrejmé $\mathrm{z}$ vyhodnotenia zadania a dotazníkových položiek, poznatky týkajúce sa modelovania a IS študenti nedokážu uchopit' a využit' na riešenie jednoduchého problému formuláciu používatel'ských požiadaviek, ktorá si vyžaduje vedomosti aplikovat', prepájat', tvorivo použivat', napriek skutočnosti že so spomínanými pojmami pracujú bežne.

Všetky práce vykazovali typické nedostatky:

- zadávatel' nie je schopný presne vyjadrit' požiadavky na systém, text je neštruktúrovaný; požiadavky sú určené nejednoznačne, grafická forma vyjadrenia sa nevyskytuje;

- požiadavkám nie sú priradené atribúty, nie je možné rozoznat' ich dôležitost';

- nie sú definované väzby medzi požiadavkami, je obtiažne navrhnút' jednotlivé subsystémy;

- zadávatel' používa vlastné výrazové prostriedky.

Vzhl'adom na to že pôsobíme na Ekonomickej fakulte TUKE je výučba informatiky zameraná na zvládnutie základných nástrojov a aplikácii s obsahom podobným ECDL, ale je nevyhnutné poskytnút' študentom aj pohl'ad na riešenie problémov dnešného podnikatel'ského prostredia.

Pri vytváraní/modifikovaní informačného systému firmy modelovanie firemných procesov slúži v súčasnosti ako prvý určujúci krok. Diagramy firemných procesov sú dobre pochopitel'né, a umožňujú špecifikovanie projektu $\mathrm{v}$ interakcii s firmou, čím sa dá vyhnút' množstvu chýb. Pri modelovaní je nutné aby sa mapovania procesov zúčastňovala samotná firma a spoluvytvárala zadanie a návrh požadovaného informačného systému.

Za účelom zvládnutia nesmierne dôležitej fázy - analýzy a modelovania podnikových ( tzv business) procesov je dnes $\mathrm{k}$ dispozícii množstvo komerčných nástrojov, s ktorými absolventi (nielen ekonomickej fakulty) môžu v praxi s vysokou pravdepodobnost'ou pracovat'. Najznámejšími, v súčasnosti používanými nástrojmi (sú okrem mnohých d’alších):

- Unified Modelling Language (UML) [11].

- Business Process Modelling Notation (BPMN) [10].

- Process Specification Language (PSL) [5].

- Integrated Enterprise Modelling (IEM) [15].

- Event-Driven Process Chain (EPC) [14].

Do osnov predmetu Informatika II v druhom semestri sme zaradili prednášky zamerané na modelovanie a základy informačných systémov. Po absolvovaní prednášok sme na katedrovom 
serveri umiestnili materiály $\mathrm{s}$ rozšíreným obsahom modelovania podnikových procesov a základov IS [11], [4]. Študenti ich využívali pri vypracovaní semestrálneho projektu s odporúčanou štruktúrou a tak mali možnost' vyskúšat' si prakticky o.i. jednoduchý e-learning. Hladali a študovali práve tie časti poskytnutých materiálov, ktoré potrebovali pri vypracovaní projektu. Poznatky museli aplikovat' a vytvárat' vlastné návrhy projektu zadania jednoduchého IS $\mathrm{v}$ rámci semestrálneho projektu.

Efektívnost' metódy learning-by-doing sa prejavila $\mathrm{V}$ podstatnom zlepšení štruktúry a obsahu vypracovaných zadaní, $\mathrm{v}$ tvorivom prístupe, hl’adaní netradičných možností pre rozšírenie funkčnosti navrhovaných IS.

Po necelom semestri štúdia boli študenti schopní vypracovat' požiadavky na jednoduchý IS v nasledovnej štruktúre:

1. Model klúčového procesu v notácii blízkej BPMN resp. ARIS. Sprievodný text obsahoval predpísané časti napr. spúšstacia udalost', vlastník a zákazník procesu, časová, materiálová náročnost' a pod.

2. Z prvej časti vyplývajúci opis navrhovaného IS $v$ textovej forme. Súčast'ou je napr. formuláciu problému, stručný opis ciel'ov, vymedzenie používatel'ov, zoznam častí a funkcií IS, väzby na okolie, požiadavky na bezpečnost', a pod.

3. Model funkčnosti systému prostredníctvom use case diagramu jazyka UML.

4. Dátový model založený na vymedzení atribútov v class diagrame UML.

$\mathrm{Na}$ nasledujúcich Obr 1 a Obr 2 uvádzame ukážku zo študentského projektu - model procesu a use case diagram.

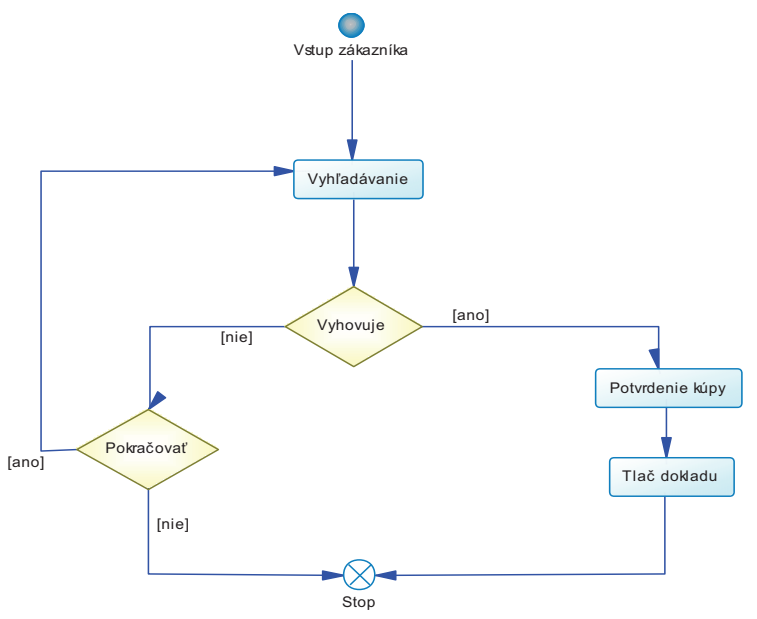

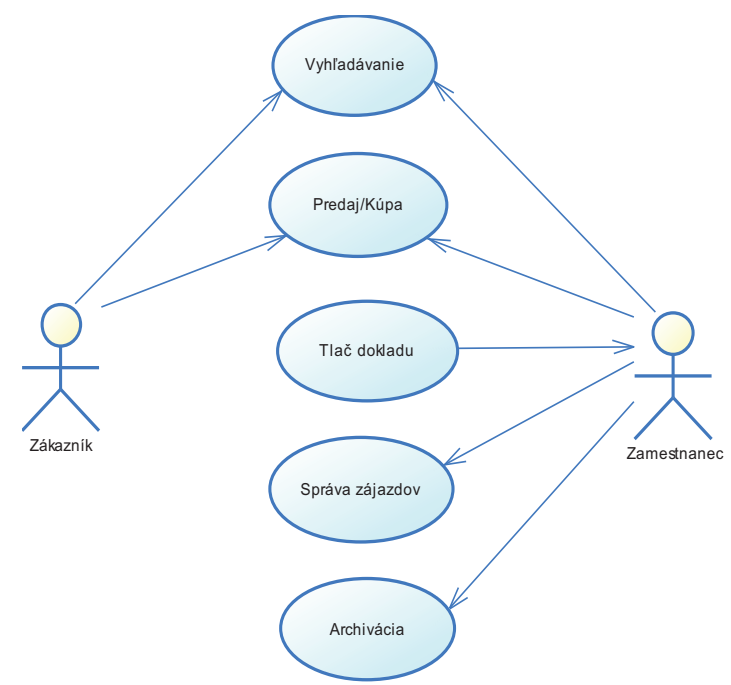

Obr 2: Use case diagram.

\section{Záver}

Riadiaci pracovníci, $\mathrm{v}$ podstatnej miere absolventi vysokých škôl (nielen ekonomického smeru) sú/budú zodpovední za správne fungovanie a maximálne využitie poznatkov informatiky v podniku. Už v roku 2000 Harvard Business Review [1] uvádza: „Dnes sa od všetkých vyšších manažérov očakáva, že budú zároveň informačnými manažérmi!“

Ak chcú vzdelávacie inštitúcie pripravit' absolventov pre pôsobenie v praxi musia prispôsobit' obsah vzdelávania, formy a použité metódy požiadavkám doby. Modelovanie je jedna z metód ktorá v súčasnom vzdelávaní nie je zastúpená dostatočne. Informácie sú iba pasívnym materiálom, ktorý musí byt' interpretovaný a premenený použitím na znalostí, aby z nich vyplynul prospech.

Nech by človek akokol'vek dlho počúval o tvorivej činnosti, nech by sa na tvorivú činnost' akokol'vek dlho pozeral, nikdy sa nenaučí tvorit', pokial' to neskúsi sám [17]. Študent dokonale pochopí učivo až ked' sa aktívne zapojí do činnosti, ktorá využíva naučené poznatky.

Informatika môže poslúžit' vo vzdelávaní ako integrujúci faktor. Podporuje modelovanie reality a tvorivé hl'adanie metód na riešenie konkrétnych problémov. Vo výučbe možno obsiahnut' komplex súvislostí, ktoré pri štúdiu z pohl'adu jedného vedného odboru ostávajú zahmlené, využit' najmodernejšie metódy pedagogických i informatických vied [3].

Obr 1: Model procesu. 


\section{Literatúra}

[1] EARL, M.: Are CIOs Obsolete?, In: Harvard Business Review, Vol 78:2, 2000.

[2] GÁlA, L. - POUR, J. - TOMAN, P.: Podniková informatika, Grada Publishing, a.s., Praha 2006, ISBN 80-247-1278-4

[3] HROMKOVIČ, J.: Informatika a všeobecné vzdelanie, in Obzory matematiky, fyziky a Informatiky 4/2001, s. 14-22 ISSN 1335-4981

[4] HUDÁKOVÁ, D. - PALOVÁ, D.: Spracovanie informácií pomocou nástrojov IKT, EkF TU Košice, 2009, ISBN 978-80-553-0294-2 [5] International Standards Organization (ISO): ISO 18629 series: Process Specification Language www.iso.org online 2010

[6] KALAŠ, I. a kol.: Informatika pre stredné školy, SPN, ISBN 80-08-01518-7

[7] KELEMEN, J. a kol.: Pozvanie do znalostnej spoločnosti, IURA Edition, Bratislava, 2007, ISBN 978-80-8078-149-1

[8] KRÁL, J.: Informační systémy, Science, Veletiny, 1998, ISBN 80-86083-00-4

[9] KUNEŠ, J. - VAVROCH, O. - FRANTA, V.: Základy modelování, SNTL Praha 1989, ISBN 80-03-00147-1

[10] OMG: Business Process Modelling Notation Specification www.omg.org, online 2010

[11] OMG: Unified Modelling Language, Superstructure v 2.1.1, www.omg.org, online 2010
[12] RÉVÉSZOVÁ, L. - PALOVÁ, D: Základy modelovania podnikových procesov, EkF Technická univerzita Košice, 2009, ISBN 97880-553-0174-7

[13] RUMBAUGH, J.E. - BLAHA, M. PREMELANI, W.J. - EDDY, F. - LORENSEN, W.: Object-Oriented Modelling and Design, Prentice-Hall International, 1991

[14] SCHEER, A.W.: ARIS - Business Process Frameworks, 2nd Edition, Berlin, 1998

[15] SPUR, G. - MERTINS, K. - JOCHEM, R. WARNECKE, H. J.: Integrierte Unternehmensmodellierung Beuth Verlag GmbH 1993

[16] ŠVECOVÁ, V.: Základy pedagogiky, TU Košice, KIP, 2000, ISBN 80-7099-483-5

[17] TUREK, I.: Didaktika technických predmetov, SPN Bratislava,1999 ISBN80-08$00587-4$

RNDr. Libuša Révészová, Ph.D.

Katedra aplikovanej matematiky

a hospodárskej informatiky

Ekonomická fakulta

Technická univerzita v Košiciach

Nemcovej 32

040 01, Košice, Slovenská republika

Tel: +421055602 3261

email: libusa.reveszova@tuke.sk

www pracoviska: www.ekf.tuke.sk 